Article

\title{
Effect of Cathode Material and Its Size on the Abundance of Nitrogen Removal Functional Genes in Microcosms of Integrated Bioelectrochemical-Wetland Systems
}

\author{
Sharvari S. Gadegaonkar ${ }^{1}$, Timothé Philippon ${ }^{2}$, Joanna M. Rogińska ${ }^{3}$, Ülo Mander ${ }^{1} \oplus$, \\ Martin Maddison ${ }^{1}$, Mathieu Etienne ${ }^{3} \mathbb{D}$, Frédéric Barrière ${ }^{2}$, Kuno Kasak ${ }^{1} \mathbb{D}^{\mathbb{D}}$, Rauno Lust ${ }^{1}$ and \\ Mikk Espenberg 1,*(i) \\ 1 Department of Geography, Institute of Ecology and Earth Sciences, University of Tartu, Vanemuise 46, \\ 51003 Tartu, Estonia; sharvari@ut.ee (S.S.G.); ulo.mander@ut.ee (Ü.M.); martin.maddison@ut.ee (M.M.); \\ kuno.kasak@ut.ee (K.K.); rauno.lust@ut.ee (R.L.) \\ 2 Campus de Beaulieu, ISCR (Institut des Sciences Chimiques de Rennes), CNRS, Université de Rennes, \\ 35000 Rennes, France; timothe.philippon@univ-rennes1.fr (T.P.); frederic.barriere@univ-rennes1.fr (F.B.) \\ 3 LCPME, CNRS, Université de Lorraine, F-54000 Nancy, France; joanna.roginska@univ-lorraine.fr (J.M.R.); \\ mathieu.etienne@univ-lorraine.fr (M.E.) \\ * Correspondence: mikk.espenberg@ut.ee
}

Received: 29 May 2020; Accepted: 31 July 2020; Published: 3 August 2020

check for updates

\begin{abstract}
Constructed wetland-microbial electrochemical snorkel (CW-MES) systems, which are short-circuited microbial fuel cells (MFC), have emerged as a novel tool for wastewater management, although the system mechanisms are insufficiently studied in process-based or environmental contexts. Based on quantitative polymerase chain reaction assays, we assessed the prevalence of different nitrogen removal processes for treating nitrate-rich waters with varying cathode materials (stainless steel, graphite felt, and copper) and sizes in the CW-MES systems and correlated them to the changes of $\mathrm{N}_{2} \mathrm{O}$ emissions. The nitrate and nitrite removal efficiencies were in range of $40 \%$ to $75 \%$ and over $98 \%$, respectively. In response to the electrochemical manipulation, the abundances of most of the nitrogen-transforming microbial groups decreased in general. Graphite felt cathodes supported nitrifiers, but nirK-type denitrifiers were inhibited. Anaerobic ammonium oxidation (ANAMMOX) bacteria were less abundant in the electrochemically manipulated treatments compared to the controls. ANAMMOX and denitrification are the main nitrogen reducers in CW-MES systems. The treatments with 1:1 graphite felt, copper, plastic, and stainless-steel cathodes showed higher $\mathrm{N}_{2} \mathrm{O}$ emissions. nirS- and nosZI-type denitrifiers are mainly responsible for producing and reducing $\mathrm{N}_{2} \mathrm{O}$ emissions, respectively. Hence, electrochemical manipulation supported dissimilatory nitrate reduction to ammonium (DNRA) microbes may play a crucial role in producing $\mathrm{N}_{2} \mathrm{O}$ in CW-MES systems.
\end{abstract}

Keywords: bioelectrochemical system; cathode material and size; constructed wetland; microbial electrochemical snorkel; microbial fuel cell; ANAMMOX; denitrification; DNRA; nitrification; nitrous oxide

\section{Introduction}

A fundamental change in the nitrogen $(\mathrm{N})$ cycle has been happening since the beginning of 20th century as anthropogenic activities have considerably increased the availability of $\mathrm{N}$ in the environment through the legume cultivation, fossil fuel combustion, and the chemical fixation process [1]. These processes are extremely important for humans because of transport and agriculture, 
but a substantial amount of $\mathrm{N}$ levels is lost unintentionally to the environment, causing a great negative impact on water quality and global warming for example [2]. $\mathrm{N}$ from intensive animal farming, manufactured fertilizer, septic systems, or other sources has raised nitrate concentrations in the waterbodies of most industrialized countries [3]. Constructed wetlands have been readily utilized for the treatment of $\mathrm{N}$-rich water and a variety of $\mathrm{N}$ forms can be removed in them through specific microbial processes, such as combined nitrification-denitrification and anaerobic ammonium oxidation (ANAMMOX) [4]. On the other hand, there are four main microbially mediated reaction pathways that may be important to generate powerful greenhouse gas nitrous oxide $\left(\mathrm{N}_{2} \mathrm{O}\right)$ in waters and sediments: incomplete denitrification, nitrification, nitrifier denitrification, and dissimilatory nitrate reduction to ammonium (DNRA) [5]. Thus, the presence or absence of these microbial communities is a crucial necessity in understanding the prevalence of $\mathrm{N}$ transformation processes in the wetland systems [6].

Bioelectrochemical systems can be considered to be an effective conjugated system to constructed wetlands for the removal of $\mathrm{N}$ from polluted water [7-9]. In addition, these systems can be very efficient for removal of organic matter in wastewater treatment [10]. These combined systems employ the ability of the electroactive microorganisms to reduce $\mathrm{N}$ compounds [11]. Besides the $\mathrm{N}$ removal from wastewater, the first thorough studies on the constructed wetland-microbial fuel cell (CW-MFC, i.e., the coupling of constructed wetlands to microbial fuel cells) systems have been used for bioenergy production, aromatic compound degradation, chemical oxygen demand (COD) removal, chromium ion removal, the microbial community of the rhizosphere, materials and geometries of the electrodes, biocathodes, and architectures [12]. The performance of the CW-MFC systems have been improved through several physiochemical and operational modifications [13,14], but the efficiency is mainly determined by the microbial communities, which perform various processes. Thus, the different microorganisms and microbe-mediated processes affected by environmental factors are crucial step to understand and improve the effectiveness of CW-MFC systems [11]. Different microbial electrochemical technologies have to overcome many obstacles in order to gain stable performance for various purposes (mainly wastewater treatment) before they can be extensively used [15-17].

The microbial electrochemical snorkel (MES) is an MFC in which there is a shortcut between the electrodes in anodic and cathodic compartments. The lack of potential difference between these two electrodes makes it unusable, when it comes to power production, however, in this configuration one can achieve a maximum current. Therefore, MES can be very efficient for removal of organic matter in wastewater treatment, hydrocarbon biodegradation and soil bioremediation [10,18]. MES systems are also already connected with CWs [19], however the number of studies using MES for nitrogen removal remains limited.

Several studies have analyzed microbial communities in MFCs [20-22], but only a limited number of studies have analyzed the abundance of functional genes regulating denitrification processes in MFCs [23-25]. No previous studies could be found on functional genes of other $\mathrm{N}$ transformation processes such as dissimilatory nitrate reduction to ammonia (DNRA), anaerobic ammonia oxidation (ANAMMOX), and complete ammonia oxidation (COMAMMOX) in MFC-CWs. Likewise, only few studies have considered greenhouse gas fluxes in MFC-CWs [9,22-24,26,27].

This study will help us in understanding the extent to which the cathode electrode influences the microbe-mediated $\mathrm{N}$ transformation processes (denitrification, nitrification, ANAMMOX, DNRA) and $\mathrm{N}_{2} \mathrm{O}$ emissions. In addition, the $\mathrm{N}_{2} \mathrm{O}$ fluxes associated with the abundance of functional genes of the sediment in the systems helps in understanding the prevailing mechanisms in the CW-MES systems. The purpose of this study was to assess the abundances of sediment bacteria and archaea and their potential to perform different nitrogen removal processes for treating nitrate-rich waters with varying cathode materials (stainless steel, graphite felt, and copper) and their sizes in microcosms of the integrated bioelectrochemical-wetland systems, and to link these changes to $\mathrm{N}_{2} \mathrm{O}$ emissions. 


\section{Materials and Methods}

\subsection{Experimental Set-Up}

The water and sediments used in the experiment were collected from the constructed wetland treating $\mathrm{N}$ rich agricultural diffuse pollution [28]. CW-MES system reactors were plastic vessels with the volume of $2 \mathrm{~L}$ with the height of $13 \mathrm{~cm}$, diameter of the bottom was $10.5 \mathrm{~cm}$ and the diameter of top was $12 \mathrm{~cm}$ (Figure 1). The level of the sediment in the reactors was approximately $7 \mathrm{~cm}$. The anodes were embedded in the sediment $3.5 \mathrm{~cm}$ above the bottom of the reactor. The material of anodes was graphite felt and their diameter was $10 \mathrm{~cm}$ and thickness $1.5 \mathrm{~cm}$. The anode was connected to cathode via stainless steel wires, which were connected with copper tape. The cathode was resting on the sediment. For most of the time, the electrodes were connected in shortcut, in CW-MES configuration, and were disconnected only for the electrochemical studies. Two parameters of the cathodes were varied and studied, namely their size and the material of cathodes. We express the varying size of graphite felt cathodes (GFD-4,6-PA) as a ratio of geometrical surfaces between the electrode in the sediment and the one in water. Therefore, the ratio described as 1:1 had the same geometrical surface of anode and cathode, while in the ratios 1:2 and 1:4, the surface of cathode was respectively 2 and 4 times smaller than the surface of anode. Diameters were $9.4,6.24$, and $3.68 \mathrm{~cm}$ respectively, with the graphite felt thickness of $0.5 \mathrm{~cm}$. In a series of experiments when the changing parameter was the cathode material, the following materials were used: graphite felt (GFD-4,6-PA) copper, plastic, and stainless steel (specifications of materials: in the Supplementary Information). In this case, the diameter of the cathode was always $8 \mathrm{~cm}$. The graphite felt (GFD-4,6-PA) was pre-treated in an ultrasonic bath in ethanol/water solutions of decreasing concentrations.

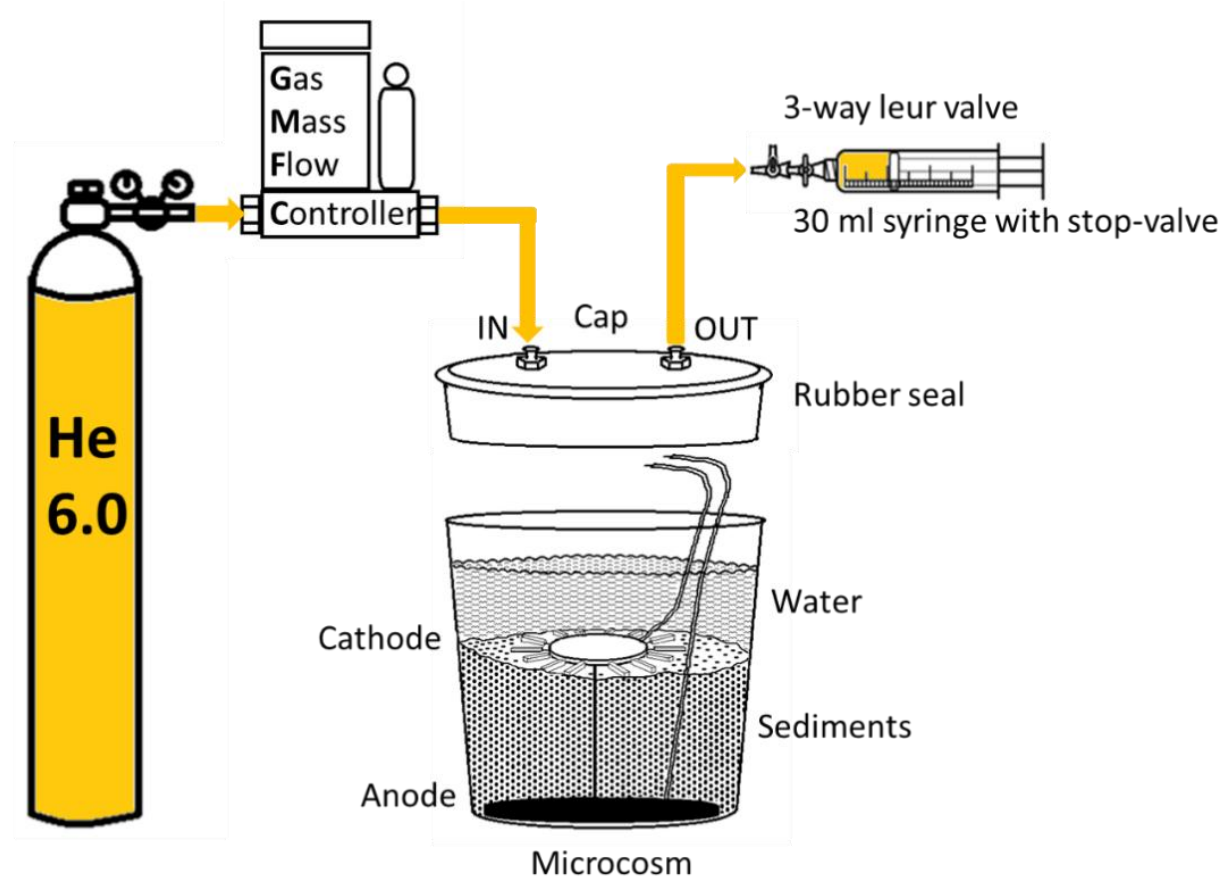

Figure 1. Schematic representation of $\mathrm{N}_{2} \mathrm{O}$ sampling from CW-MES (the coupling of constructed wetlands to microbial fuel cells) systems, where anode is embedded in the sediment and connected via copper connections to cathode, which rest on the sediment.

The different materials, i.e., graphite felt, plastic, stainless steel, and copper and varying ratios, i.e., 1:1 cathode, 1:2 cathode, and 1:4 cathode were used in order to study the effect of cathode material and its size on the abundance of the $\mathrm{N}$ transformation genes present in the bioelectrochemical systems. For the control, we used two systems where one system was without any electrodes and the second 
without cathode but had an anode embedded in the sediment. Every treatment was carried out in triplicate, and in all, 27 separate CW-MES systems were created. All other connections were made using copper wires.

The systems were operated for 45 days in a dark room at room temperature. To imitate the nitrate-rich waters, the reactors were added with $50 \mathrm{mg} \mathrm{N}-\mathrm{NO}_{3}-/ 1$ on days 9,13 , and 24 . No external polarization was applied to the electrodes that were left connected in short circuit.

\subsection{Sediment and Water Sampling}

Sediment samples (ca 5-20 g each) from CW-MES reactors were collected in the beginning of the experiment (day 1), in the middle of the experiment (day 18) and at the end of the experiment (day 45) and stored at $-20^{\circ} \mathrm{C}$. Dissolved nitrogen (DN), dissolved carbon (DC), and dissolved organic carbon (DOC) were determined in the sediment samples using a Vario TOC cube (Elementar Analysensysteme GmbG, Langenselbold, Germany), following EVS-EN 12260, EVS-EN 1484, and EVS-EN 1484 standards, respectively.

Water samples from the CW-MES reactors were collected every three days. Nitrate, nitrite, and sulfate concentrations were determined from the water samples using Ion chromatograph Metrohm 930 Compact IC Flex, the column used was Metrosep A Supp5 100/4.0 with the effluent composition of $1.0 \mathrm{mM} \mathrm{NaHCO}_{3}$ and $3.2 \mathrm{mM} \mathrm{Na}_{2} \mathrm{CO}_{3}$.

\section{3. $\mathrm{N}_{2} \mathrm{O}$ Sampling and Analysis}

The CW-MES reactors were sampled once a week for $\mathrm{N}_{2} \mathrm{O}$. For gas sampling, the vessel of the CW-MES reactor was closed tightly with the rubber seal and plastic cap, where the latter had connections for carrier gas inlet and gas sampling (Figure 1). Helium 6.0 was used to purged to the headspace of the vessel. The silicon tubes were evacuated with syringe before sampling. Gas samples from the headspace of the vessel were collected into a previously evacuated $(0.3 \mathrm{mbar}) 30 \mathrm{~mL}$ glass vial in every 40 min during a 2-h session (sample time-points: 0, 40, 80, and $120 \mathrm{~min}$ ) using a polypropylene syringe. The $\mathrm{N}_{2} \mathrm{O}$ concentration from the samples was analyzed using Shimadzu GC-2014 gas chromatography equipped with an electron capture detector (ECD) and Loftfield's autosampler [29].

\subsection{DNA Extraction}

The DNA was extracted from $0.25 \mathrm{~g}$ of the sediment samples using the PowerSoil DNA Isolation kit (MO BIO Laboratories Inc, Carlsbad, CA, USA) according to the described manufacturer's protocol. Homogenizer Precellys 24 (Berlin Technologies, Montigny-le-Bretonneux, France) was used for the homogenization of the samples at $5000 \mathrm{rpm}$ for $20 \mathrm{~s}$. The concentrations and the quality of the extracted DNA was analyzed using the spectrophotometer Infinite M200 (Tecan AG, Grodig, Austria). The extracted DNA samples were stored in $-20^{\circ} \mathrm{C}$.

\subsection{Quantitative Polymerase Chain Reaction ( $q P C R$ )}

The qPCR assays were performed using RotorGene ${ }^{\circledR}$ Q equipment (Qiagen, Valencia, CA, USA). qPCR was used for 16S rRNA genes amplification to evaluate the abundance of the bacterial and the archaeal communities. For estimation of $\mathrm{N}$ transformation processes, nirK (copper-containing nitrite reductase gene, denitrification), nirS (cytochrome cd1-type nitrite reductase gene, denitrification), nosZI (clade I nitrous oxide reductase gene, denitrification), nosZII (clade II nitrous oxide reductase gene, denitrification); bacterial amo $A$ (ammonia monooxygenase gene, nitrification), archaeal amo $A$ (ammonia monooxygenase gene, nitrification), ANAMMOX-specific 16S rRNA (anaerobic ammonia oxidation), and $n r f A$ (cytochrome c nitrite reductase gene, DNRA) genes were quantified by qPCR. The used gene-specific primer sets, optimized thermal cycling conditions, and primer concentrations for each target gene are described by Espenberg et al. [6]. The modifications in characteristics of the used qPCR primers and programs compared to Espenberg et al. [6]: forward primer nirSCd3af [30] 
was used instead of nirSC1F; annealing temperature of qPCR program: nirS $\left(55^{\circ} \mathrm{C}\right)$, bacterial amoA $\left(57^{\circ} \mathrm{C}\right)$, ANAMMOX $16 \mathrm{~S}$ rRNA $\left(52^{\circ} \mathrm{C}\right)$.

The quantification data were analyzed with RotorGene Series Software v. 2.0.2 (Qiagen, Hilden, Germany) and LinRegPCR program v. 2020.0 [31]. The abundance of each target gene was presented per gram of dry soil (copies/g dw). The abundance of total prokaryotic organisms was calculated by summing the bacterial and archaeal $16 \mathrm{~S}$ rRNA gene abundances. The proportion of target genes and microbial groups in soil microbial community was estimated by normalizations against prokaryotic community. The used qPCR method is described in more detail by Espenberg et al. [6].

\subsection{Electrochemical Study}

Small pieces of the cathodes of each pilot were collected at day 20 and were then studied by cyclic voltammetry as the working electrode using a potentiostat (910 PSTAT mini Metrohm) in a three electrodes configuration cell. The reference electrode was $\mathrm{Ag} / \mathrm{AgCl}(+0.197 \mathrm{~V}$ vs. SHE) and the scan rate was $1 \mathrm{mV} \mathrm{s}^{-1}$. A stainless-steel rod was used as counter electrode. Two cycles were recorded and only the second one is shown. The cathode reactor samples were studied in a $0.1 \mathrm{M}$ sodium chloride electrolyte prepared in pure water. The electrolyte was degassed with helium bubbling prior to the experiment in order to remove dissolved oxygen. The cyclic voltammograms were recorded before and after addition of $10 \mathrm{mM}$ sodium nitrate $\left(\mathrm{NaNO}_{3}\right)$ to test for potential nitrate bio-electrochemical reduction by microbes at the surface of the cathode samples.

The cathode- and anode electrode polarizations were identified every other day in each pilot. For that a reference electrode was submerged into the sediment and the potential between the reference electrode and the cathode- or anode electrode was measured with a multimeter. During the experiment two different reference electrodes were used $\mathrm{Ag} / \mathrm{AgCl}$ (+0.197 V vs. SHE) and saturated calomel electrode (SCE $+0.244 \mathrm{~V}$ vs. SHE). To make data comparison easier, the polarizations were converted against SHE.

\subsection{Statistical Analysis}

We used R version 3.6.3 (R Core Team, 2020) to explore, harmonize, analyze, and visualize the data. To evaluate the significance of the differences between studied treatments with respect to physicochemical variables, gene parameters, and emission values, multivariate linear models were constructed, and models were tested using the ANOVA function in R package mvabund v. 4.1.3 [32]. Spearman's rank correlation coefficients were used to assess the relationships between target gene parameters and environmental factors. The $p$-values were also adjusted for the false discovery rate by the Benjamini-Hochberg method with significance at $p<0.05$ and $p<0.01$. Spearman correlation networks were visualized with Cytoscape v. 3.7.2 [33].

\section{Results}

\subsection{Physicochemical Properties, Nitrate Removal and $\mathrm{N}_{2} \mathrm{O}$ Flux}

Sediment DC and DOC values of CW-MES showed significant difference between treatments ( $p<0.05$ and $p<0.01$, respectively), although sediment DN concentration remained similar $(p>0.05)$ (Figure 2). Throughout the study period DC, DOC, and DN values showed completely different temporal trend in Controls compared to other treatments as their concentration rather increased and was the highest in the last day of experiment (Supplementary Figure S1). The CW-MES were significantly different regarding the nitrate and sulfate concentration in the water $(p<0.05$ and $p<0.01$, respectively). The nitrite concentrations were very low and showed no significant difference between treatments $(p>0.05)$. Treatment 1:1 graphite felt increases nitrite for a while but not in a long-term perspective (Supplementary Figure S1). 


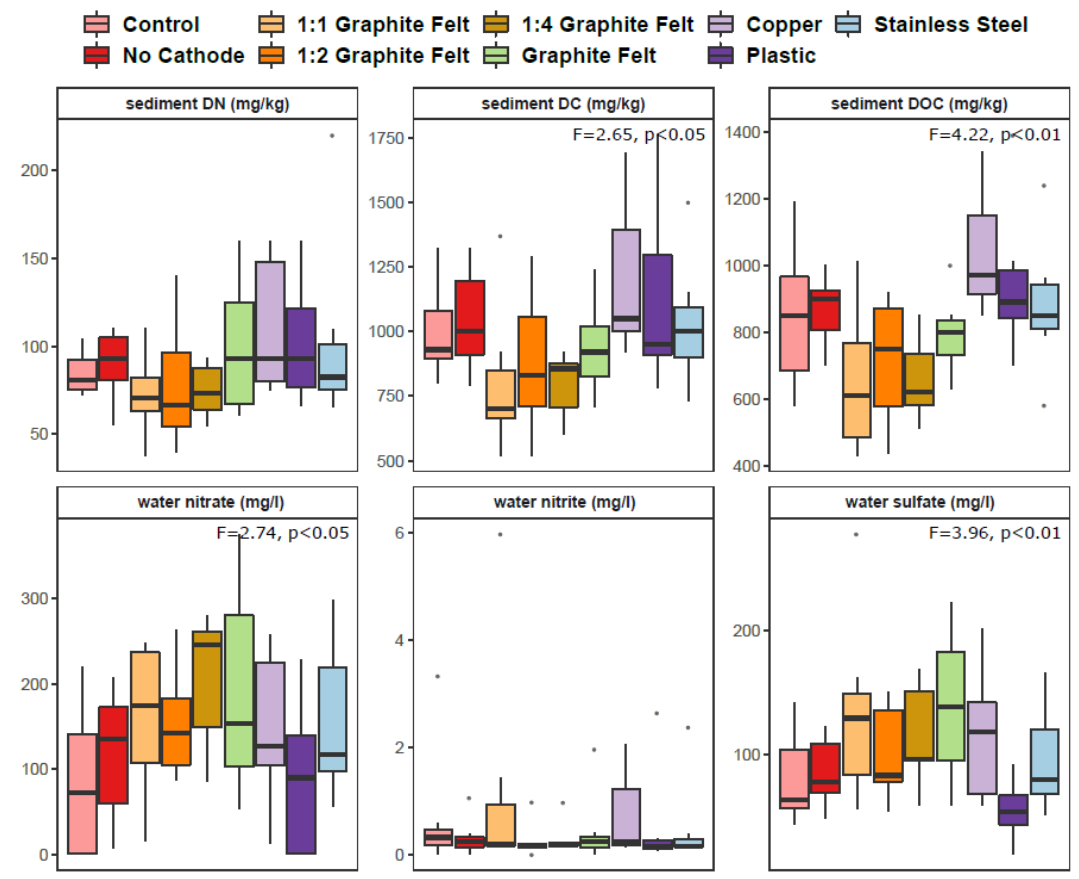

Figure 2. Box plots of sediment and water parameters in nine studied treatments (each $n=6$ ). Statistically significant differences between groups considering different genes are shown with $\mathrm{F}$ and $p$ values determined by multivariate analysis. The central line is the median, the edges of the box are the 25 th and 75th percentiles, the whiskers represent the $95 \%$ confidence interval, and grey dots indicate outliers. Abbreviations: DN-dissolved nitrogen, DC-dissolved carbon, DOC-dissolved organic carbon.

The water parameters for inorganic substrates, i.e., nitrate, nitrite and sulfate were also analyzed over the course of the experiment, nitrate and sulfate showed significant differences between treatments ( $p<0.05$ in both cases) (Figure 3). The trend in nitrate, nitrite, and sulfate concentrations remains similar during the sediment sampling days and throughout the experiment. No statistical differences were discernible in $\mathrm{N}_{2} \mathrm{O}$ emission values directly before soil sampling between treatments $(p>0.05)$ (Figure 3). The $\mathrm{N}_{2} \mathrm{O}$ emissions throughout the experimental duration displayed highest emissions for the treatments with cathodes 1:1 graphite felt, copper, plastic, and stainless steel.

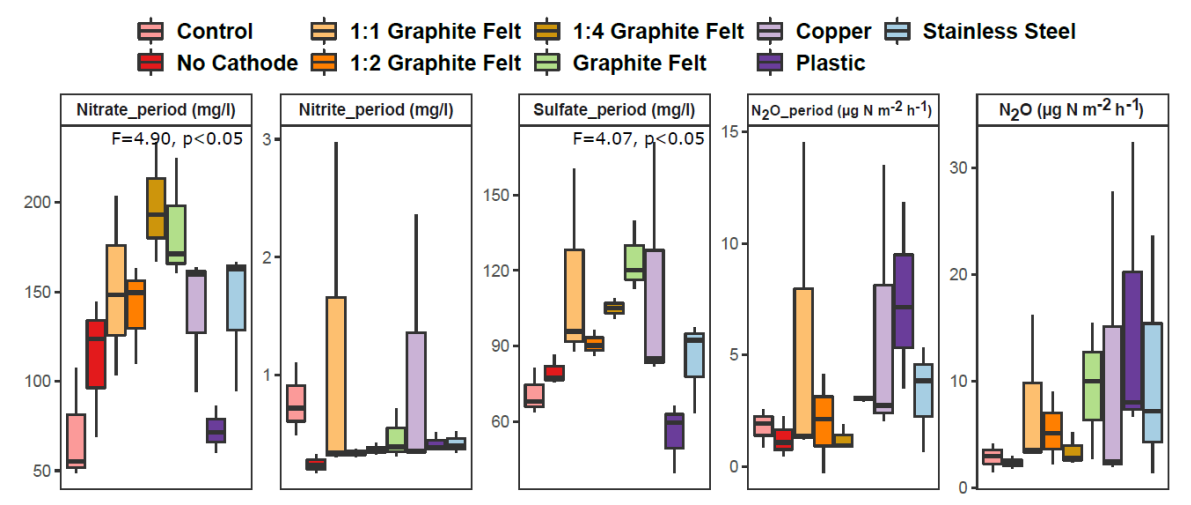

Figure 3. Box plots of water parameters and gas emissions in nine studied treatments. Statistically significant differences between groups considering different genes are shown with F and $p$ values determined by multivariate analysis. The central line is the median, the edges of the box are the 25 th and 75 th percentiles, the whiskers represent the $95 \%$ confidence interval, and grey dots indicate outliers. Period denotes average values throughout the experiment (each $n=3$ ). $\mathrm{N}_{2} \mathrm{O}$ _period denotes average $\mathrm{N}_{2} \mathrm{O}$ emission values throughout the experiment. $\mathrm{N}_{2} \mathrm{O}$ denotes $\mathrm{N}_{2} \mathrm{O}$ emission values directly before soil sampling (each $n=6$ ). 
Nitrate removal efficiency was highly variable in different treatments (Table 1). Treatments with plastic cathodes showed the highest nitrate removal efficiency followed by control and no cathode systems. All other systems showed slightly lower nitrate removal efficiency, which was less than $50 \%$. Nitrite removal efficiency on the other hand was very high (over 98\%) in all the studied systems.

Table 1. Average $(n=3)$ and standard deviation of nitrate and nitrite removal efficiency (\%).

\begin{tabular}{ccc}
\hline Treatment & Nitrate Removal & Nitrite Removal \\
\hline Control & $66.51 \pm 1.54$ & $98.66 \pm 0.42$ \\
No Cathode & $53.88 \pm 23.52$ & $99.37 \pm 0.08$ \\
1:1 Graphite Felt & $48.39 \pm 29.05$ & $98.07 \pm 2.31$ \\
1:2 Graphite Felt & $41.35 \pm 15.27$ & $99.40 \pm 0.06$ \\
1:4 Graphite Felt & $41.52 \pm 6.99$ & $99.33 \pm 0.11$ \\
Graphite Felt & $41.18 \pm 13.67$ & $99.00 \pm 0.20$ \\
Copper & $40.55 \pm 26.70$ & $99.39 \pm 0.27$ \\
Plastic & $74.61 \pm 7.22$ & $99.39 \pm 0.27$ \\
Stainless steel & $40.34 \pm 9.88$ & $99.25 \pm 0.22$ \\
\hline
\end{tabular}

3.2. Sediment Microbial Community Abundance and Proportion in the Prokaryotic Community-Denitrification, Nitrification, ANAMMOX and DNRA Process-Based Genes

qPCR results showed that the total abundance of archaea differed significantly between the sediments of treatments $(p<0.05)$, although that was not the case for the total abundance of bacteria $(p>0.05)$ (Figure 4). Latter still showed somewhat higher abundance in the two controls (control and no cathode). No significant differences were not recognized in proportions of bacteria and archaea in prokaryotic communities over the CW-MES sediments ( $p>0.05$ in both cases) (Supplementary Figure S2). The bacterial $16 \mathrm{~S}$ rRNA genes were found in more abundance than the archaeal 16SrRNA genes in the sediment samples. In addition, it seems that 1:1 graphite felt decreases the total gene abundances of bacteria and archaea as well as functional genes compared to other treatments, although the same trend was not noticed in the target gene proportions of the prokaryotic communities. Throughout the whole experiment period in most of the treatments, the temporal dynamics of the bacterial 16S rRNA gene parameters showed somewhat decreasing trend and the archaeal 16S rRNA gene parameters showed somewhat increasing trend, except for the control in both cases (Figure 5; Supplementary Figure S3).

nirS, nirK, nosZI, nosZII, bacterial and archaeal amoA, ANAMMOX-specific 16S rRNA genes were detected in all sediment samples, whereas $n r f A$ genes were not detected in sediments of one parallel of No Cathode, Graphite Felt, and 1:2 Graphite Felt treatments (Figure 4; Supplementary Figure S2). Based on average values of the gene parameters, the abundances of the functional gene copy numbers and the functional gene proportions in the prokaryotic communities were declining in order as follows: nirS, nirK, nosZII, nosZI, ANAMMOX-specific $16 \mathrm{~S}$ rRNA, archaeal amoA, bacterial amoA, nrfA. In the all sediments, the archaeal amo $A$ genes abundance exceeded the bacterial $a m o A$ abundance by ca one order of magnitude and nirS and nosZII genes were found to be around two-fold more abundant than nirK and nosZI genes, respectively.

The total abundance of archaeal amoA, nirK, nosZII, and ANAMMOX-specific 16S rRNA gene copy numbers varied significantly between the sediments of the treatments $(p<0.05, p<0.01, p<0.05$ and $p<0.01$, respectively) (Figure 4). In addition, nirS proportions in the prokaryotic communities showed significant difference in the treatments' sediments $(p<0.05)$ (Supplementary Figure S2). The total abundance of almost all studied functional genes was roughly higher in the two controls (control and no cathode) than other treatments. The only exception was determined for $n r f A$ genes (both the total abundances and the proportions in the prokaryotic community), which were in the same level or showed even higher values in the treatments with electrochemical manipulation compared to the controls. All denitrification genes (nirS, nirK, nosZII, nosZI) showed lower abundances in treatments of 1:1 Graphite Felt and Graphite Felt compared to others. A decrease in the ANAMMOX-specific 16S 
rRNA gene total abundances and proportions in the prokaryotic community was reported regarding the treatments with electrochemical manipulation.

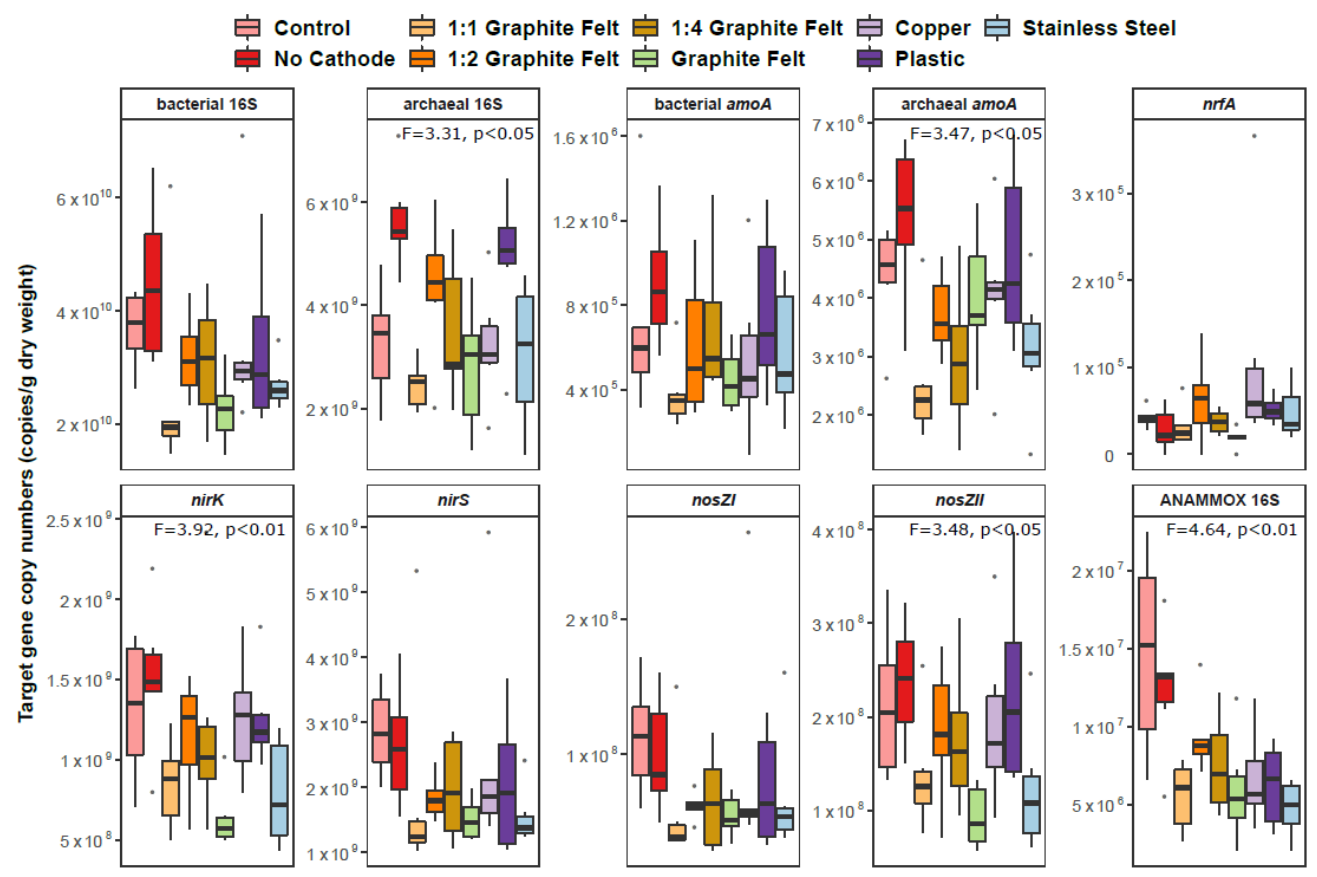

Figure 4. Box plots of target gene copy numbers in nine studied treatments (each $n=6$ ). Statistically significant differences between groups considering different genes are shown with $\mathrm{F}$ and $p$ values determined by multivariate analysis. The central line is the median, the edges of the box are the 25 th and 75 th percentiles, the whiskers represent the $95 \%$ confidence interval, and grey dots indicate outliers.

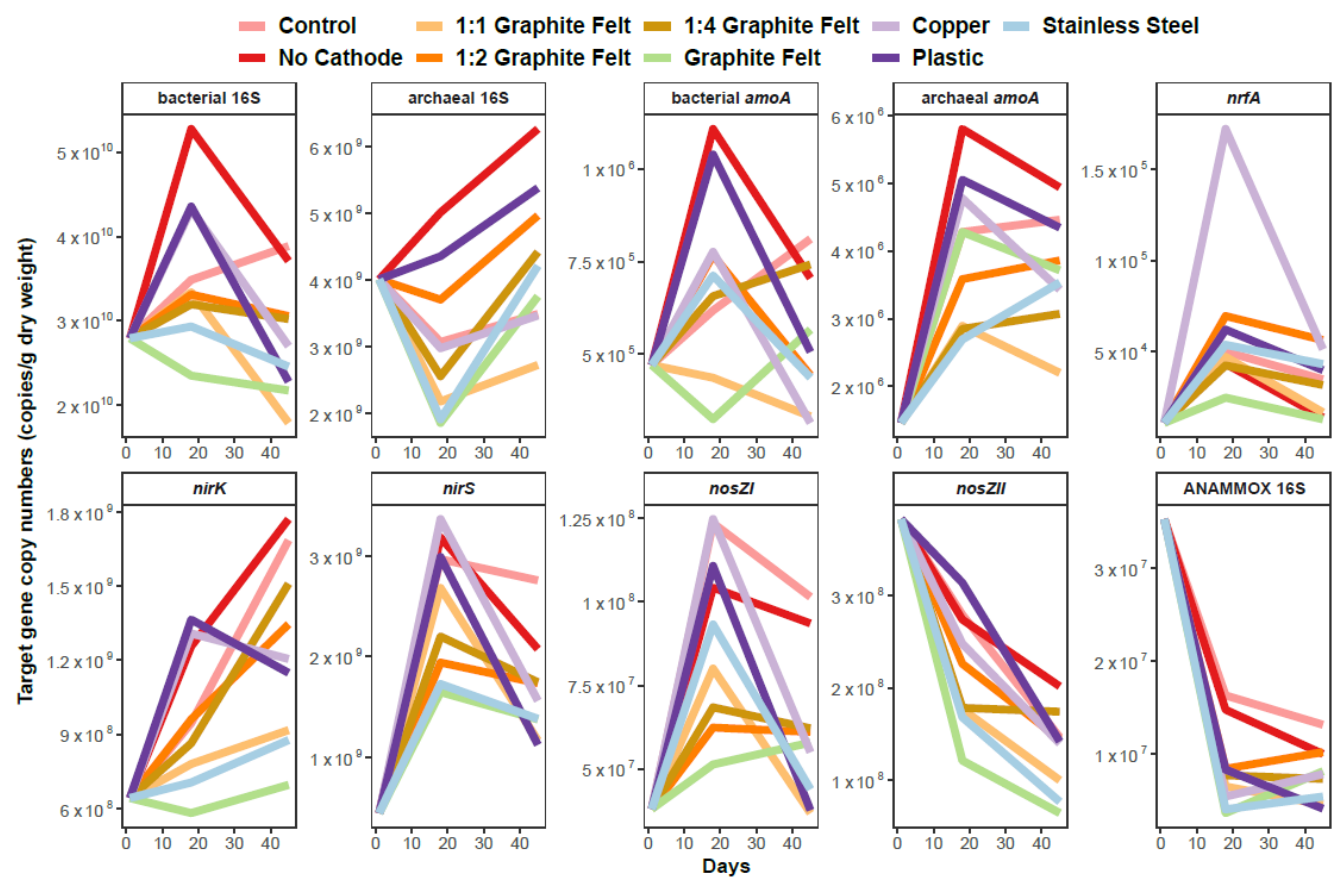

Figure 5. Temporal dynamics of different gene abundances during the experiment (each $n=3$ ).

The temporal trend followed by all treatments were similar in terms for the different functional genes in most cases (Figure 5; Supplementary Figure S3). In general, nir, nosZI, nrfA and archaeal 
amo $A$ genes have shown a rise in their copy numbers and also in their proportions in prokaryotic community, when to compare the beginning and end of the experiment. The nosZII genes showed a fall in both abundances and proportions (in prokaryotic community) throughout the experiment. The substantial decline in described gene parameters was observed of the ANAMMOX-specific $16 \mathrm{~S}$ rRNA gene during the full experiment period. Some opposite trends were noticed between treatments in temporal scale regarding bacterial amoA gene parameters. In case of treatments with the graphite felt cathode, clear opposite trends are apparent for bacterial amo $A$ gene and archaeal amo $A$ genes, while nirK genes seemed to be inhibited.

\subsection{Relationships between Target Genes, Physicochemical Parameters and $\mathrm{N}_{2} \mathrm{O}$ Flux}

The data analysis detected several statistically significant relationships between target gene parameters and environmental factors, while all treatments, except two controls (control and no cathode), were analyzed together (Figure 6). The sediment DC and DN concentrations showed positive correlations with the abundances of bacterial 16S rRNA, nirS, nosZI, nosZII, and nrfA genes $(p<0.05$ in all cases), while negative correlations were observed between DC and DN values and nirK and ANAMMOX-specific $16 \mathrm{~S}$ rRNA genes proportions in the prokaryotic community ( $p<0.05$ in all cases). Similarly, the sediment DOC concentration was related to the abundances of bacterial 16S rRNA, nirS, and $n r f A$ genes and ANAMMOX-specific $16 \mathrm{~S}$ rRNA genes proportions in the prokaryotic community $(p<0.05$ in all cases). Positive correlation between water nitrate concentration and archaeal amoA proportion was revealed $(p<0.05)$, while this chemical factor had negative relationship with archaeal $16 \mathrm{~S}$ rRNA abundance and nirK proportion $(p<0.05$ in both cases). The water nitrite content was related positively to nirS proportion $(p<0.05)$ and negatively to nosZII and ANAMMOX-specific $16 \mathrm{~S}$ rRNA genes proportions ( $p<0.05$ in both cases). Only negative relationships between water sulfate concentration and nosZII and nrfA gene parameters were revealed by a correlation analysis $(p<0.01$ and $p<0.05$, respectively).

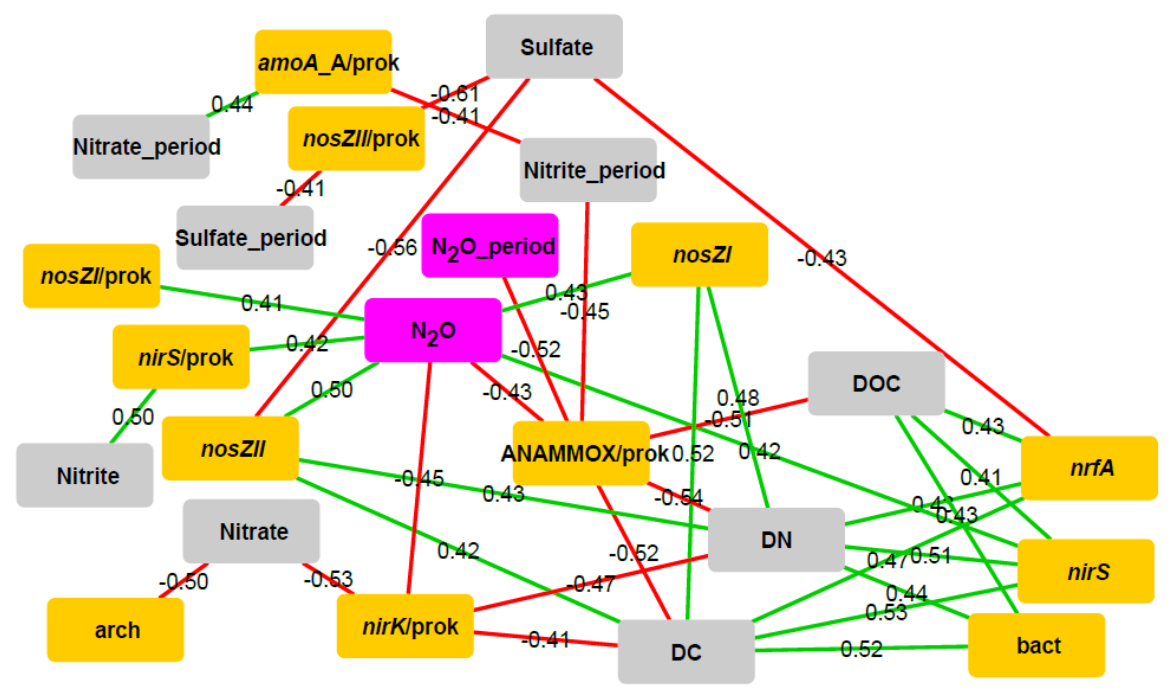

Figure 6. The Benjamini-Hochberg corrected Spearman correlation network $(p<0.05)$ for each target gene parameter and environmental factor pair $(n=42)$. Green is used to represent positive relationships, and red indicates negative relationships (exact $R$ values are shown on the graph); yellow stands for gene abundances, grey for soil physicochemical variables and pink for gaseous parameters. Abbreviations: DN-dissolved nitrogen, DC-dissolved carbon, DOC-dissolved organic carbon, period-average values throughout the experiment, bact-bacterial 16S rRNA gene abundance, arch-archaeal 16S rRNA gene abundance, prok-prokaryotic community (total bacterial and archaeal 16S rRNA gene proportion), amoA_A-archaeal amoA gene abundance, ANAMMOX-anaerobic ammonia oxidation-specific 16S rRNA gene abundance, $\mathrm{N}_{2} \mathrm{O}-\mathrm{N}_{2} \mathrm{O}$ emission. 
The proportion of nirK and ANAMMOX-specific $16 \mathrm{~S}$ rRNA genes correlated negatively with $\mathrm{N}_{2} \mathrm{O}$ emission from the CW-MES systems ( $p<0.05$ in both cases). In addition, the abundance of nirS, nosZI, and nosZII genes and the proportion of nirS and nosZI genes were correlated positively with $\mathrm{N}_{2} \mathrm{O}$ emission from the CW-MES systems ( $p<0.05$ in all cases).

Several significant relationships more appeared, but they were not confirmed by the Benjamini-Hochberg correction (Figure S4). Nevertheless, these relationships may have also indications to important processes in the CW-MES systems, although they should be taken into account with reservations. Sediment DC, DOC and DN contents were all positively related to abundances of bacterial and archaeal amoA genes ( $p<0.05$ in all cases). Water nitrate concentration showed different relationships with nirS, nirK, $n r f A$ and bacterial $16 \mathrm{~S}$ rRNA genes ( $p<0.05$ in all cases). Water nitrite concentration was related to different genes (nirS, nosZI, nosZII, bacterial amoA, and archaeal 16S rRNA genes) quite differently $(p<0.05$ in all cases). Water sulfate content was still negatively correlated with most of the studied different gene parameters ( $p<0.05$ in all cases). Functional gene $n r f A$ abundance showed positive correlation with $\mathrm{N}_{2} \mathrm{O}$ from the CW-MES systems $(p<0.05)$. The proportion of nos $\mathrm{ZI}$ in the prokaryotic community was positively correlated with one-time measurements of $\mathrm{N}_{2} \mathrm{O}(p<0.05)$, but negatively with the average $\mathrm{N}_{2} \mathrm{O}$ emission values throughout the experiment $(p<0.05)$.

\subsection{Electrochemical Measurements}

Cyclic voltammetry study on cathode reactor samples showed a reduction system for two out of three replicates equipped with graphite felt cathodes (Figure 7 and Supplementary Figure S5). No similar reduction peaks were obtained with the other cathode materials. For the first pilot (graphite felt 1), a reduction peak is visible at $-0.3 \mathrm{~V}$ vs. $\mathrm{Ag} / \mathrm{AgCl}$ under helium saturation before nitrate addition and the peak current of this system increases after nitrate addition. The second pilot (graphite felt 2) shows an even clearer difference with no reduction at all in the case of helium saturation and no nitrate addition, with a clear reduction peak appearing after nitrate supplementation at the same potential of $-0.3 \mathrm{~V}$ vs. $\mathrm{Ag} / \mathrm{AgCl}$.
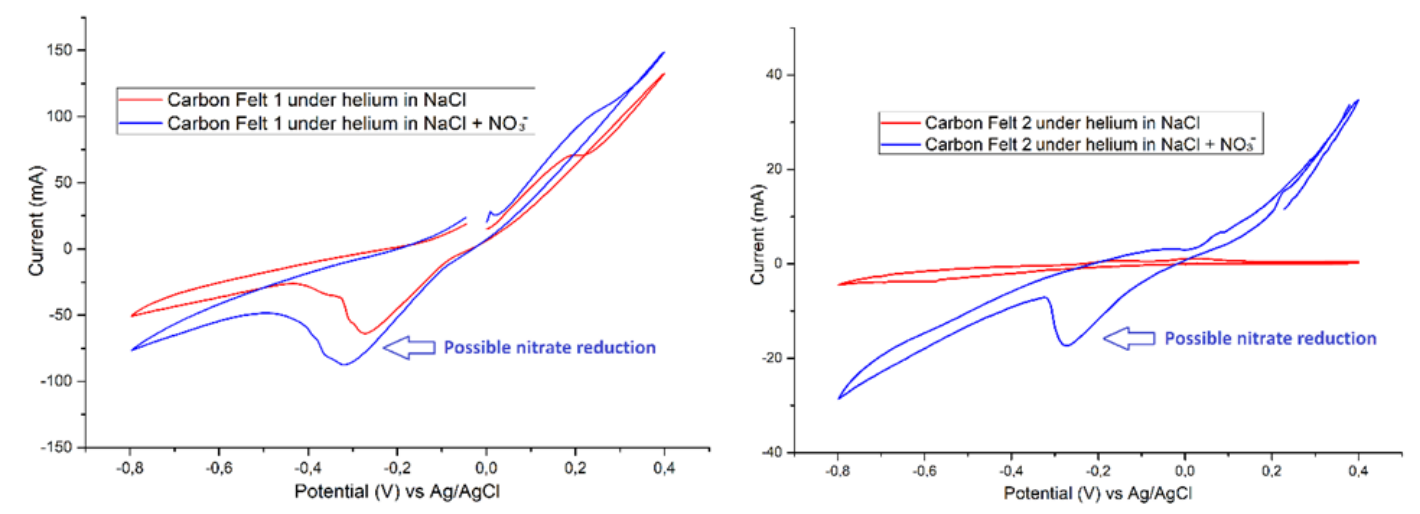

Figure 7. Different cyclic voltammograms of carbon felt (i.e., graphite felt) before and after Sodium Nitrate addition in the electrolyte under helium saturation. Possible nitrate reduction is showed by blue arrows.

Average polarizations of the cathode electrodes were $+0.136,-0.02$, and $-0.166 \mathrm{~V}$ vs. SHE for carbon felt, copper and stainless-steel electrodes, respectively. And the average polarizations of the anode electrodes were $-0.03,-0.08$, and $-228 \mathrm{~V}$ vs. SHE for carbon felt, copper, and stainless-steel electrodes, respectively. 


\section{Discussion}

The capability of microorganisms to produce electrical current or to accept and use electrons continues to be a high-potential approach and strategy for developing sustainable water treatment technologies [11,34]. However, bioelectrochemical systems have present a challenge to face for several reasons, e.g., no conserved functional genes exist to specifically target electrochemically active microorganisms [11]. Thus, one of the best options is to examine mechanisms underlying microbial-mediated in CW-MES and other electrochemical systems through process-based genes from the microbiological perspective. Denitrification has received the greatest attention regarding electrochemical systems [23-25], although there is a rising interest in other and newly discovered processes (e.g., ANAMMOX and DNRA), because they can be crucial in the N dynamics [11].

The results of this study showed nitrate removal efficiencies in range of $40-75 \%$ and the highest removal efficiency was detected in treatments with plastic cathodes. All the treatments containing graphite felt cathodes removed nitrate from the CW-MES systems in a quite similar level. In treatments with graphite felt cathodes, nitrate reduction was also demonstrated by cyclic voltammetry. The cathode materials were tested independently after the experiments for their potential nitrate reduction ability: only two graphite felt cathodes showed an electrochemical response to nitrate addition at $-0.3 \mathrm{~V}$, which suggests that the biofilm on these cathodes may harbor electroactive denitrifying microorganisms $[35,36]$. Nitrite removal efficiencies were over $98 \%$ in all studied treatments of CW-MES systems.

Our results showed that electrochemically manipulated treatments all in all rather decreased the abundance of bacteria compared to controls, which may indicate the community shift because of the effect of the treatment. The electrotrophic activity among bacteria and archaea seems to be not very widely spread. However, the diversity of electroactive bacterial, archaeal, and eukaryotic microorganisms is constantly increasing due to the discovery of new electroactive microorganisms [11]. However, MFCs are not definable only by electroactive organisms [37-39] the microbial cooperation is ubiquitous in nature and helps microorganisms to overcome biological and thermodynamic limitations in different environments [40]. Based on our results, archaea account for ca 5-20\% of all prokaryotes in CW-MES systems and change in archaeal abundance between the controls and other treatments seemed to be smaller compared to bacteria. Archaea are widely present in many environments and they possess unique features [41], and maybe, they are also quite resilient to electrochemical manipulation or even this manipulation enhance the abundance of archaea.

In addition, we can notice that the genes in the controls, i.e., control with no electrodes, no cathode control with just the anode electrode, and plastic as the cathode material, i.e., non-conductive electrode, displayed the highest number of abundances for many of the target $\mathrm{N}$ transformation genes. The fall in the target gene copy numbers in some other treatments can be attributed to the electrons passing through the system hampering the count of the microbes, thereby reducing the observed copy numbers in the conductive systems. Furthermore, the larger the size of the electrodes more is the conductivity and the reduction rate but when bio-electrochemical systems come into picture the major catalysts are the microbes and therefore, they should not burn out due to higher current through the systems. For example, some versions of graphite felt cathodes treatment (1:1 graphite felt and the systems in which graphite felt was used as a cathode material) lessen the abundances of bacteria, archaea as well as functional genes (especially denitrification genes) compared to other treatments, but this tendency was not seen in the target gene proportions of the prokaryotic community.

We found that the balance between bacterial $a m o A$ and archaeal amo $A$ genes was in favor of latter genes in CW-MES systems. In both engineered and natural environments, the domination and activity of bacterial or archaeal ammonia oxidizers depend on mainly on factors like substrate concentration, temperature, light, $\mathrm{pH}$, and oxygen [42]. Nitrification seemed to be suppressed to some extent in different treatments with cathodes as controls showed higher abundance of archaeal amoA possessing microbes. Treatment with graphite felt supported amoA-harbouring archaea or bacteria depending on physicochemical conditions, whereas nirK-type denitrifiers were somewhat inhibited. 
The abundance of nir was significantly higher than nosZ in CW-MES systems, although the nirSand nosZII-type denitrifiers were more abundant in prokaryotic community, compared to denitrifiers possessing nirK and nosZI genes, respectively. In general, temporal dynamics of nirS- and nosZI-type denitrifiers were very similar and of nirK and nosZII-type denitrifiers showed almost opposite trend during the experiment. This can be attributed to the facts that there is higher frequency of co-occurrence of nosZ with nirS than with nirK (only $10-30 \%$ of the nirK-type denitrifiers also carry the nosZ gene) and most of the nosZI-types possess nirK or nirS (ca half of nosZII-harbouring microbes lack nir genes) [43]. Our results indicated that the abundance of all denitrification genes was smaller in the treatments with cathodes than controls, which may mean a similar trend of the community shift, as discussed above about bacteria. Different treatments altered significantly the abundances of nirS, nirK, and nosZII-type denitrifiers.

Electrochemical activity has been recently confirmed in highly enriched cultures of the ANAMMOX bacteria ('Candidatus Brocadia sinica' and 'Candidatus Scalindua sp.'), in spite of the fact that their electroactive potential and characteristics have been really scarcely studied [11]. In our CW-MES systems, the abundance of ANAMMOX bacteria was different between treatments and they were less abundant in the treatments with cathodes than controls. Accordingly, it may indicate their reluctance to electrochemical actions, despite some of their possible electroactive features or it would be also explained due to the presence of low amounts of nitrite in the water, which must have curbed the microbes involved in carrying out ANAMMOX processes.

In our CW-MES systems, microorganisms conducting DNRA seemed not to be affected too much of the electrochemical manipulation, and some of the treatments showed even higher abundances and proportions of DNRA microbes compared to the controls. The rise in the $n r f A$ gene copy numbers may be attributed to their diverse metabolic pathways of DNRA microbes, which allow them to thrive at varying environments [44]. The DNRA retain the amount of nitrogen in the system by converting the nitrite into ammonium and thus, the rise in $n r f A$ possessing organisms could have possibly led to ammonium generation, thereby influencing the rise in the amo $A$-harbouring microbes.

Our results indicated that gene parameters relationships with sediment DC, DOC and DN and water nitrite and nitrate concentrations revealed a competition regarding those essential nutrients. Rivalry was mainly between denitrification and ANAMMOX and less with nitrification. Water sulfate content inhibited the abundance of all the major N-cycle genes.

From an environmental sustainability point of view, $\mathrm{N}_{2} \mathrm{O}$ emissions should be also estimated and considered in designs of CW-MFC systems [27]. In our CW-MES systems, the treatments with 1:1 graphite felt, copper, plastic, and stainless-steel cathodes showed higher $\mathrm{N}_{2} \mathrm{O}$ emissions compared to others throughout the study period. $\mathrm{N}_{2} \mathrm{O}$ emissions could be mainly attributed to nirS-type denitrifiers, although there were some indications that DNRA microbes may also play a crucial role in producing $\mathrm{N}_{2} \mathrm{O}$ in CW-MES systems. nosZI-type denitrifiers were for the most part responsible for reducing $\mathrm{N}_{2} \mathrm{O}$ emissions.

\section{Conclusions}

The results of this study show high nitrate and nitrite removal efficiencies in CW-MES systems. In response to the electrochemical manipulation, the abundances of bacterial, archaeal, and most of the N-transforming microbial groups decreased. Treatment with graphite felt cathodes supported nitrifying archaea or bacteria depending on the physicochemical conditions, but nirK-type denitrifiers were inhibited. ANAMMOX bacteria were less abundant in the treatments with cathodes than controls and their electroactive potential is in ambiguity. However, ANAMMOX bacteria and denitrifiers are the main $\mathrm{N}$ reducers in CW-MES systems. The treatments with 1:1 graphite felt, copper, plastic, and stainless-steel cathodes showed higher $\mathrm{N}_{2} \mathrm{O}$ emissions compared to others throughout the study period. nirS- and nosZI-type denitrifiers are mainly responsible for producing and reducing $\mathrm{N}_{2} \mathrm{O}$ emissions, respectively. There is some evidence that DNRA microbes are assisted by electrochemical manipulation and may also play a crucial role in producing $\mathrm{N}_{2} \mathrm{O}$ in CW-MES systems. 
Supplementary Materials: The following are available online at http://www.mdpi.com/2571-8789/4/3/47/s1, Figure S1. Temporal dynamics of different sediment and water parameters during the experiment $($ each $n=3)$. Abbreviations: DN—dissolved nitrogen, DC—dissolved carbon, DOC—dissolved organic carbon, Figure S2. Box plots of target gene copy numbers proportion in the prokaryotic community in nine studied treatments (each $n=6$ ). Statistically significant differences between groups considering different genes are shown with $\mathrm{F}$ and $p$ values determined by multivariate analysis. The central line is the median, the edges of the box are the 25th and 75th percentiles, the whiskers represent the $95 \%$ confidence interval, and grey dots indicate outliers, Figure S3. Temporal dynamics of different gene proportions in the prokaryotic community during the whole experiment (for each $n=3$ ), Figure S4. Spearman correlation network $(p<0.05)$ for each target gene parameter and environmental factor pair $(n=42)$ which were left out after the Benjamini-Hochberg correction. Green is used to represent positive relationships, and red indicates negative relationships (exact $\mathrm{R}$ values are shown on the graph); yellow stands for gene abundances, grey for soil physicochemical variables and pink for gaseous parameters. Abbreviations: DN—dissolved nitrogen, DC—dissolved carbon, DOC—dissolved organic carbon, period - average values throughout the experiment, bact-bacterial 16S rRNA gene abundance, arch-archaeal 16S rRNA gene abundance, prok-prokaryotic community (total bacterial and archaeal 16S rRNA gene proportion), amoA_B-bacterial amo $A$ gene abundance, amo $A$ _A - archaeal amo $A$ gene abundance, $\mathrm{N}_{2} \mathrm{O}-\mathrm{N}_{2} \mathrm{O}$ emission, Figure S5. Different cyclic voltammograms of carbon felt i.e., graphite felt before and after Sodium Nitrate addition in the electrolyte under helium saturation and ambient air. Possible nitrate reduction is showed by blue arrows.

Author Contributions: Conceptualization, T.P., J.M.R., M.E. (Mikk Espenberg), and Ü.M.; methodology, T.P., J.M.R., M.M., S.S.G., and M.E. (Mikk Espenberg); software, M.E. (Mikk Espenberg); validation, T.P., J.M.R., S.S.G., M.M., M.E. (Mikk Espenberg), and Ü.M.; formal analysis, M.E. (Mikk Espenberg) and S.S.G.; investigation, T.P., J.M.R., S.S.G., M.M., M.E. (Mikk Espenberg), and K.K.; resources, Ü.M.; data curation, S.S.G., M.E. (Mikk Espenberg), and M.M.; writing—original draft preparation, S.S.G., M.E. (Mikk Espenberg), Ü.M., and M.M.; writing一review and editing, S.S.G., M.E. (Mikk Espenberg), Ü.M., T.P., J.M.R., M.E. (Mathieu Etienne), F.B., R.L., K.K., and M.M.; visualization, M.E. (Mikk Espenberg), S.S.G., M.M., and T.P.; supervision, M.E. (Mikk Espenberg), Ü.M., M.E. (Mathieu Etienne), and F.B.; project administration, M.E. (Mikk Espenberg), Ü.M., M.E. (Mathieu Etienne), and F.B.; funding acquisition, Ü.M., M.E. (Mathieu Etienne), and F.B. All authors have read and agreed to the published version of the manuscript.

Funding: This study was supported by the Estonian Research Council (PUTJD715, IUT2-16, PRG352 and PRG676); the EU through the European Regional Development Fund (Centre of Excellence EcolChange, Estonia) and by the European Structural and Investment Funds. The financial support from The French National Research Agency (ANR-17-CE04-0004) is gratefully acknowledged. The financial support from the International mobility support for PhD students-DrEAM (University of Lorraine) is gratefully acknowledged.

Acknowledgments: We thank Alar Teemusk for analyzing gas samples.

Conflicts of Interest: The authors declare no conflict of interest.

\section{References}

1. Galloway, J.N.; Leach, A.M.; Bleeker, A.; Erisman, J.W. A chronology of human understanding of the nitrogen cycle. Philos. Trans. R. Soc. B Biol. Sci. 2013, 368, 20130120. [CrossRef] [PubMed]

2. Rockström, J.; Steffen, W.; Noone, K.; Persson, Å.; Chapin, F.S.; Lambin, E.F.; Lenton, T.M.; Scheffer, M.; Folke, C.; Schellnhuber, H.J.; et al. A safe operating space for humanity. Nature 2009, 461, 472-475. [CrossRef] [PubMed]

3. Fields, S. Global Nitrogen: Cycling out of Control. Environ. Health Perspect. 2004, 112, A556-A563. [CrossRef] [PubMed]

4. Lee, C.; Fletcher, T.D.; Sun, G. Nitrogen removal in constructed wetland systems. Eng. Life Sci. 2009, 9, 11-22. [CrossRef]

5. Quick, A.M.; Reeder, W.J.; Farrell, T.B.; Tonina, D.; Feris, K.P.; Benner, S.G. Nitrous oxide from streams and rivers: A review of primary biogeochemical pathways and environmental variables. Earth-Sci. Rev. 2019, 191, 224-262. [CrossRef]

6. $\quad$ Espenberg, M.; Truu, M.; Mander, Ü.; Kasak, K.; Nõlvak, H.; Ligi, T.; Oopkaup, K.; Maddison, M.; Truu, J. Differences in microbial community structure and nitrogen cycling in natural and drained tropical peatland soils. Sci. Rep. Nat. Publ. Group 2018, 8, 1-12. [CrossRef]

7. Zhang, B.; Liu, Y.; Tong, S.; Zheng, M.; Zhao, Y.; Tian, C.; Liu, H.; Feng, C. Enhancement of bacterial denitrification for nitrate removal in groundwater with electrical stimulation from microbial fuel cells. J. Power Sources 2014, 268, 423-429. [CrossRef]

8. Jain, A.; He, Z. Cathode-enhanced wastewater treatment in bioelectrochemical systems. Npj Clean Water 2018, 1, 1-5. [CrossRef] 
9. Lust, R.; Nerut, J.; Kasak, K.; Mander, Ü. Enhancing Nitrate Removal from Waters with Low Organic Carbon Concentration Using a Bioelectrochemical System-A Pilot-Scale Study. Water 2020, 12, 516. [CrossRef]

10. Hoareau, M.; Erable, B.; Bergel, A. Microbial electrochemical snorkels (MESs): A budding technology for multiple applications. A mini review. Electrochem. Commun. 2019, 104, 106473. [CrossRef]

11. Logan, B.E.; Rossi, R.; Ragab, A.; Saikaly, P.E. Electroactive microorganisms in bioelectrochemical systems. Nat. Rev. Microbiol. 2019, 17, 307-319. [CrossRef]

12. Guadarrama-Pérez, O.; Gutiérrez-Macías, T.; García-Sánchez, L.; Guadarrama-Pérez, V.H.; Estrada-Arriaga, E.B. Recent advances in constructed wetland-microbial fuel cells for simultaneous bioelectricity production and wastewater treatment: A review. Int. J. Energy Res. 2019, 43, 5106-5127. [CrossRef]

13. Ferapontova, E.E. Effect of cation adsorption on the kinetics of anion electroreduction: Part II. Effect of the adsorption of organic cations in small concentrations on the kinetics of anion electroreduction. J. Electroanal. Chem. 1999, 476, 37-45. [CrossRef]

14. Shi, Y.; Yang, X.; Ning, X.; Yang, Q. Research progress of microbial fuel cell and constructed wetland coupling system. IOP Conf. Ser. Earth Environ. Sci. 2018, 199, 052014. [CrossRef]

15. Santoro, C.; Arbizzani, C.; Erable, B.; Ieropoulos, I. Microbial fuel cells: From fundamentals to applications. A review. J. Power Sources 2017, 356, 225-244. [CrossRef]

16. Alonso, R.M.; San-Martín, M.I.; Mateos, R.; Morán, A.; Escapa, A. Scale-Up of Bioelectrochemical Systems for Energy Valorization of Waste Streams. In Microbial Electrochemical Technologies; Tiquia-Arashiro, S.M., Pant, D., Eds.; CRC Press: Boca Raton, FL, USA, 2000; pp. 447-459. [CrossRef]

17. Sánchez, C.; Dessì, P.; Duffy, M.; Lens, P.N.L. Microbial electrochemical technologies: Electronic circuitry and characterization tools. Biosens. Bioelectron. 2020, 150, 111884. [CrossRef]

18. Erable, B.; Etcheverry, L.; Bergel, A. From microbial fuel cell (MFC) to microbial electrochemical snorkel (MES): Maximizing chemical oxygen demand (COD) removal from wastewater. Biofouling 2011, 27, 319-326. [CrossRef]

19. Ramírez-Vargas, C.A.; Arias, C.A.; Carvalho, P.; Zhang, L.; Esteve-Núñez, A.; Brix, H. Electroactive biofilm-based constructed wetland (EABB-CW): A mesocosm-scale test of an innovative setup for wastewater treatment. Sci. Total Environ. 2019, 659, 796-806. [CrossRef]

20. Xiao, Y.; Zheng, Y.; Wu, S.; Yang, Z.-H.; Zhao, F. Bacterial community structure of autotrophic denitrification biocathode by 454 pyrosequencing of the 16S rRNA gene. Microb. Ecol. 2015, 69, 492-499. [CrossRef]

21. Zhao, J.; Wu, J.; Li, X.; Wang, S.; Hu, B.; Ding, X. The Denitrification Characteristics and Microbial Community in the Cathode of an MFC with Aerobic Denitrification at High Temperatures. Front. Microbiol. 2017, 8, 9. [CrossRef]

22. Wang, G.; Guo, Y.; Cai, J.; Wen, H.; Mao, Z.; Zhang, H.; Wang, X.; Ma, L.; Zhu, M. Electricity production and the analysis of the anode microbial community in a constructed wetland-microbial fuel cell. RSC Adv. 2019, 9, 21460-21472. [CrossRef]

23. Van Doan, T.; Lee, T.K.; Shukla, S.K.; Tiedje, J.M.; Park, J. Increased nitrous oxide accumulation by bioelectrochemical denitrification under autotrophic conditions: Kinetics and expression of denitrification pathway genes. Water Res. 2013, 47, 7087-7097. [CrossRef] [PubMed]

24. Vilar-Sanz, A.; Puig, S.; García-Lledó, A.; Trias, R.; Balaguer, M.D.; Colprim, J.; Bañeras, L. Denitrifying Bacterial Communities Affect Current Production and Nitrous Oxide Accumulation in a Microbial Fuel Cell. PLoS ONE 2013, 8, e63460. [CrossRef] [PubMed]

25. Srinivasan, V.N.; Butler, C.S. Ecological and Transcriptional Responses of Anode-Respiring Communities to Nitrate in a Microbial Fuel Cell. Environ. Sci. Technol. 2017, 51, 5334-5342. [CrossRef] [PubMed]

26. Cecconet, D.; Bolognesi, S.; Callegari, A.; Capodaglio, A.G. Controlled sequential biocathodic denitrification for contaminated groundwater bioremediation. Sci. Total Environ. 2019, 651,3107-3116. [CrossRef] [PubMed]

27. Wang, X.; Tian, Y.; Liu, H.; Zhao, X.; Peng, S. The influence of incorporating microbial fuel cells on greenhouse gas emissions from constructed wetlands. Sci. Total Environ. 2019, 656, 270-279. [CrossRef] [PubMed]

28. Kasak, K.; Kill, K.; Pärn, J.; Mander, Ü. Efficiency of a newly established in-stream constructed wetland treating diffuse agricultural pollution. Ecol. Eng. 2018, 119, 1-7. [CrossRef]

29. Loftfield, N.; Flessa, H.; Augustin, J.; Beese, F. Automated Gas Chromatographic System for Rapid Analysis of the Atmospheric Trace Gases Methane, Carbon Dioxide, and Nitrous Oxide. J. Environ. Qual. 1997, 26, 560-564. [CrossRef] 
30. Kandeler, E.; Deiglmayr, K.; Tscherko, D.; Bru, D.; Philippot, L. Abundance of narG, nirS, nirK, and nosZ Genes of Denitrifying Bacteria during Primary Successions of a Glacier Foreland. Appl. Environ. Microbiol. 2006, 72, 5957-5962. [CrossRef]

31. Ruijter, J.M.; Ramakers, C.; Hoogaars, W.M.H.; Karlen, Y.; Bakker, O.; Van den Hoff, M.J.B.; Moorman, A.F.M. Amplification efficiency: Linking baseline and bias in the analysis of quantitative PCR data. Nucleic Acids Res. 2009, 37, e45. [CrossRef]

32. Wang, Y.; Naumann, U.; Wright, S.T.; Warton, D.I. Mvabund-an R package for model-based analysis of multivariate abundance data. Methods Ecol. 2012, 3, 471-474. [CrossRef]

33. Shannon, P.; Markiel, A.; Ozier, O.; Baliga, N.S.; Wang, J.T.; Ramage, D.; Amin, N.; Schwikowski, B.; Ideker, T. Cytoscape: A software environment for integrated models of biomolecular interaction networks. Genome Res. 2003, 13, 2498-2504. [CrossRef] [PubMed]

34. Wang, X.; Aulenta, F.; Puig, S.; Esteve-Núñez, A.; He, Y.; Mu, Y.; Rabaey, K. Microbial electrochemistry for bioremediation. Environ. Sci. Ecotechnol. 2020, 1, 100013. [CrossRef]

35. Pous, N.; Koch, C.; Colprim, J.; Puig, S.; Harnisch, F. Extracellular electron transfer of biocathodes: Revealing the potentials for nitrate and nitrite reduction of denitrifying microbiomes dominated by Thiobacillus sp. Electrochem. Commun. 2014, 49, 93-97. [CrossRef]

36. Kato, S.; Hashimoto, K.; Watanabe, K. Microbial interspecies electron transfer via electric currents through conductive minerals. Proc. Natl. Acad. Sci. USA 2012, 109, 10042-10046. [CrossRef] [PubMed]

37. Summers, Z.M.; Fogarty, H.E.; Leang, C.; Franks, A.E.; Malvankar, N.S.; Lovley, D.R. Direct exchange of electrons within aggregates of an evolved syntrophic coculture of anaerobic bacteria. Science 2010, 330, 1413-1415. [CrossRef]

38. Qu, Y.; Feng, Y.; Wang, X.; Logan, B.E. Use of a Coculture to Enable Current Production by Geobacter sulfurreducens. Appl. Environ. Microbiol. 2012, 78, 3484-3487. [CrossRef]

39. Bourdakos, N.; Marsili, E.; Mahadevan, R. A defined co-culture of Geobacter sulfurreducens and Escherichia coli in a membrane-less microbial fuel cell. Biotechnol. Bioeng. 2014, 111, 709-718. [CrossRef]

40. Morris, B.E.L.; Henneberger, R.; Huber, H.; Moissl-Eichinger, C. Microbial syntrophy: Interaction for the common good. FEMS Microbiol. Rev. 2013, 37, 384-406. [CrossRef]

41. Moissl-Eichinger, C.; Pausan, M.; Taffner, J.; Berg, G.; Bang, C.; Schmitz, R.A. Archaea Are Interactive Components of Complex Microbiomes. Trends Microbiol. 2018, 26, 70-85. [CrossRef]

42. Stein, L.Y. Insights into the physiology of ammonia-oxidizing microorganisms. Curr. Opin. Chem. Biol. 2019, 49, 9-15. [CrossRef] [PubMed]

43. Hallin, S.; Philippot, L.; Löffler, F.E.; Sanford, R.A.; Jones, C.M. Genomics and Ecology of Novel N 2 O-Reducing Microorganisms. Trends Microbiol. 2018, 26, 43-55. [CrossRef] [PubMed]

44. Song, B.; Lisa, J.A.; Tobias, C.R. Linking DNRA community structure and activity in a shallow lagoonal estuarine system. Front. Microbiol. 2014, 5, 460. [CrossRef] [PubMed] 